\title{
THE INFLUENCE OF BOARD CHARACTERISTICS AND STATE HOLDING ON CORPORATE SOCIAL RESPONSIBILITY DISCLOSURE, EVIDENCE FROM VIETNAMESE LISTED FIRMS
}

\author{
Thi Lien Huong NGUYEN(1) Nhat Minh TRAN(12*, Manh Chien VU(1)3 \\ ${ }^{1}$ Faculty of Finance and Banking, Thuongmai University, Hanoi, Vietnam \\ ${ }^{2}$ Faculty of Business and Management, National Economics University, Hanoi, Vietnam \\ ${ }^{3}$ Faculty of Accounting and Auditing, Thuongmai University, Hanoi, Vietnam
}

Received 2 September 2020; accepted 18 January 2021

\begin{abstract}
Analysing the nexus between board diversity, CEO power, state holding, and corporate social responsibility disclosure in an emerging country: Vietnam, where some listed firms are held significantly by the State, is the fundamental objective of this study. In order to achieve this goal, we employed regression analysis using panel data. While board diversity consists of board gender diversification and board independence and CEO (executive) power, consisting of executive duality, executive holding (ownership), and deputy CEO, and state ownership are explanatory variables, and CSR disclosure is a dependent variable. The sample contains of 166 Vietnamese listed firms at the Hanoi Stock Exchange (HNX) for 2014-2016. After performing regression analysis, the result revealed that the proportion of female directors, deputy CEO, and state holding had a significant correlation with CSR publication. In contrast, the proportion of independent directors, CEO duality, and CEO ownership was found to be insignificant. Our research adds to the research on firm governance and CSR in several approaches. First, the paper adds to the study on the advancement of research toward corporate social responsibility and firm governance and CEO features impress on it. Second, our research expands CSR literature in developing countries, which has not been treated in detail. Fourth, this research advances and adds literature to some theories, including agency theory and resource-based view theory.
\end{abstract}

Keywords: board diversity, CEO power, CSR disclosure, state ownership, Vietnamese listed firms, agency theory, resourcebased view theory.

JEL Classification: M140.

\section{Introduction}

Corporate social responsibility (CSR) concept is attracting business consideration at both national and international levels. CSR can be defined by words that constitute the term CSR. In brief, CSR is the obligation of business (all types of enterprises) for what is caused by their activities, which impact on their stakeholders, including "communities, nations, the world, other living organisms, and the natural environment" (Tran \& Pham, 2020). Many scholars have argued that social responsibility strategic not only improves enterprise reputation. It also helps enterprises carry out more favorable investment procedures, increase labor productivity, sales revenue, raise prestige and trademark, and attract more laborers. Thus, CSR has become a critical business strategy for many enterprises in the world.
According to economics literature, a significant amount of research paper has been published in CSR related field because of its long history of development. However, because of the distinction in culture and society between nations, CSR should be considered as a "dynamic and socially constructed concept" (Malik et al., 2020). Thus, developing countries are different from developed countries in terms of CSR, emerging a need for CSR research in developing countries. This study's goal is to contribute to this research gap by undertaking Vietnam in this particular context. In Vietnam, CSR's concept is quite new when international organizations introduce it in 2002. Thus, many Vietnamese companies have been facing the problem of applying CSR due to their lack of CSR knowledge (Van \& Nguyen, 2019). Moreover, many CSR policies have not been fully completed, while the penalties for not complying with CSR laws are quite low.

*Corresponding author. E-mail: minhtn@neu.edu.vn

Copyright $\odot 2021$ The Author(s). Published by Vilnius Gediminas Technical University

This is an Open Access article distributed under the terms of the Creative Commons Attribution License (http://creativecommons.org/licenses/by/4.0/), which permits unrestricted use, distribution, and reproduction in any medium, provided the original author and source are credited. 
Consequently, many firms fail to comply with the legal requirements of the business, financial statements, environment, and labor safety.

In Vietnam, the listed firm's information disclosure is carried out following the Law on Securities 2006 amended and supplemented in 2010 and mostly Circular 155/2015 / TT. -BTC on 06/10/2015 of the Department of Finance replacing the Circular No 52/2012 / TT-BTC regulating the stock market's information disclosure. However, the stock market's information disclosure still has some shortcomings that may affect the transparency, publicity, and sustainable development of the Vietnam stock market (Tran, 2017). Apart from a small number of listed companies disclose full corporate social responsibility information under Circular 155, most businesses do not seriously study and fully disclose social responsibility (Tran, 2017). In another research, $\mathrm{Vu}$ et al. (2011) also indicated that most Vietnamese listed firms show low disclosure quantity levels.

The board of directors (BOD) is one of the vital firm governance issues, which attracts many scholars and contributes a significant role in CSR decision making. The choices, motives impact CSR disclosure quality, and the management board's values, which formulates and takes decisions in firms (Khan et al., 2013). Scholars placed great emphasis on addressing various BOD-related issues. Ferrero-Ferrero et al. (2015) suggested that the greater diversification of boards not only improves information resources, but it also enhances the cognitive and behavior range. In our study, resource-based view theory and agency theory are used to answer some questions relating to board diversity's significance on CSR disclosure. Moreover, previous research indicates that CEO power could play an essential role in CSR study. We will test this relationship by incorporating independent variables, including CEO duality and CEO ownership. In a transition country like Vietnam, state-owned enterprises contribute about onethird of the country's GDP (Kabir \& Thai, 2017). Thus, we also consider state ownership as an independent variable that should be tested.

Our literature adds to the knowledge of CSR literature in many different aspects. First, the study adds to business literature and the awareness of the status of corporates' CSR disclosure by testing the effects of executive power, board diversity, and state ownership in a developing country. Second, this study is particularly relevant to undeveloped countries where CSR knowledge is relatively weak because this awareness is perceived as worthless, and the State still holds a substantial share in the listed firm. Third, there is a shortage of papers measuring CSR through multiple dimensions, especially in developing countries like Vietnam (Katmon et al., 2019). Thus, we use the CSR disclosure index collected from quantitative, qualitative, and narrative information on annual sustainable reports and covering numerous aspects of CSR: Environment, Energy, Product Quality, Employment Relation, and Society
Involvement. Fourth, this research advances and adds literature to some theories, including agency theory and resource-based view (RBV), by clarifying the influence of board diversity and CEO power on CSR in Vietnam. Fifth, stockholders, policymakers, professional organizations, and government, considering CSR in Vietnam, can find a useful, practical contribution from this study.

This work is arranged into five parts. After the introduction section, section 1 includes reviews and hypotheses. Section 2 illustrates the methodology used, including information on the sample, data collection, and econometric model. Section 3 is the outcomes and analysis, followed by section 4 , which writes the discussion. The main conclusion is shown in the final section.

\section{Literature review and hypothesis}

A large and growing body of study has tested board diversity as one of the most critical factors in the field of firm governance research which impacts on firm's decision making. Diversity in boards is defined as various compositions of attributes, characteristics, and BOD expertise. It refers to board process and corporate decisions, including observable and unobservable factors (e.g., age, ethnicity, education, gender, and work experience). Due to globalization and the increasing diversity in the workforce, board diversity is becoming more popular as an advantage to firms because it enhances corporate decision quality, improves problem-solving, organizational competitiveness and firm performance.

The significance of board diversification can be demonstrated from several underlying theoretical perspectives, such as agency theory and resource-based view theory (RBV). This theory indicates that the heterogeneity of firms' performance origins from their internal resource endowment that is "valuable, rare, unique, and non-substitutable", which can create a superior competition (Katmon et al., 2019). Drawing on RBV theory, board diversity indicates base and dynamic capability of board, which enhances the competence of a corporate (Katmon et al., 2019). This approach also suggests that the diversity of board, proxied by capabilities, skills, experience, knowledge and gender, bring to businesses valuable internal resources from board directors, which advances to the firm's competitive level, consisting of better decisionmaking and higher economic results. In terms of CSR, a more heterogeneous board enhances understanding and problem-solving to solve CSR related issues and encourages positively for CSR. Similarly, Hoang et al. (2018) also showed that a more varied board would be able to bring advantages to CSR.

According to the research conducted by Fama and Jensen (1983), agency theory suggests that because of the segregation of leadership and ownership in organizations, managers' interests and the benefit of shareholders are not aligned mutually. Hence, the responsibility of the board of governors is to secure management team act, agreeing 
with the interest of shareholders. When the board becomes more diverse, it leads to board independence and promotes monitoring of management. In this situation, a board independence makes firms tend to preserve their reputation and image by improving information transparency to reduce agency costs. Moreover, board independence is necessary to monitor and govern sustainable development issue. This is because, the independence of board provides new insights for management and protect environmental and social stakeholders (Naciti, 2019).

CEO power is an important variable that can impact significantly on corporate decisions. CEO tenure, CEO holding and family executive status are considered as the indicators of CEO power. Agency theory research shows that a dominant $\mathrm{CEO}$ can exert a greater influence on corporate decision-making and decrease the capacity of the board. However, a powerful executive can also involve in considerable discussion, conflict and solve a boarder range of opinions (Zahra \& Pearce, 1989). The relationship between executives' power and firm's CSR has been investigated by a considerable amount of papers. Most of their findings revealed that the relationship between executives' power and the status of CSR performance is negative. In the scope of our research, we use executives' duality and executives' ownership to measure executives' power and assess the impact of them on CSR disclosure.

To sum up, the factors studied, which have an impact on CSR disclosure, are presented in Figure 1 below.

\section{Board gender diversity}

The greater gender diversification in the boards of governors can advance the process of decision - making as this involves taking into account different points of view and opinions and assessing different results. Based on RBV theory, the collaboration between male and female director on the board can be considered as a "competitive advantage". This is because of the multiplicity of the process and style of decision - making and problem - solving originating from a widerspread scope of viewpoints, better connection and a higher precise critical analysis of the problems, which leads to better decisions (Milliken \& Martins, 1996).

There are several previous studies that have illustrated female participant on boards may improve the board's consideration to ethical issues. This is because female directors turn to react faster and more assuredly toward sustainable issues. Furthermore, they are more collegial, gentle, sympathetic and sensitive than men and have good social and ethical behaviours (Ben-Amar et al., 2017). Ben-Amar et al. (2017) also suggested that the attention of women to and the thought of the feeling of others may promote them to deal with strategic issues, affecting the company and its stakeholders. As a result, female participant on board can improve the board's ability to solve effectively with issues of social responsibility for corporates.

In terms of CSR, the majority of studies illustrated that more female directors on the govern board can contribute

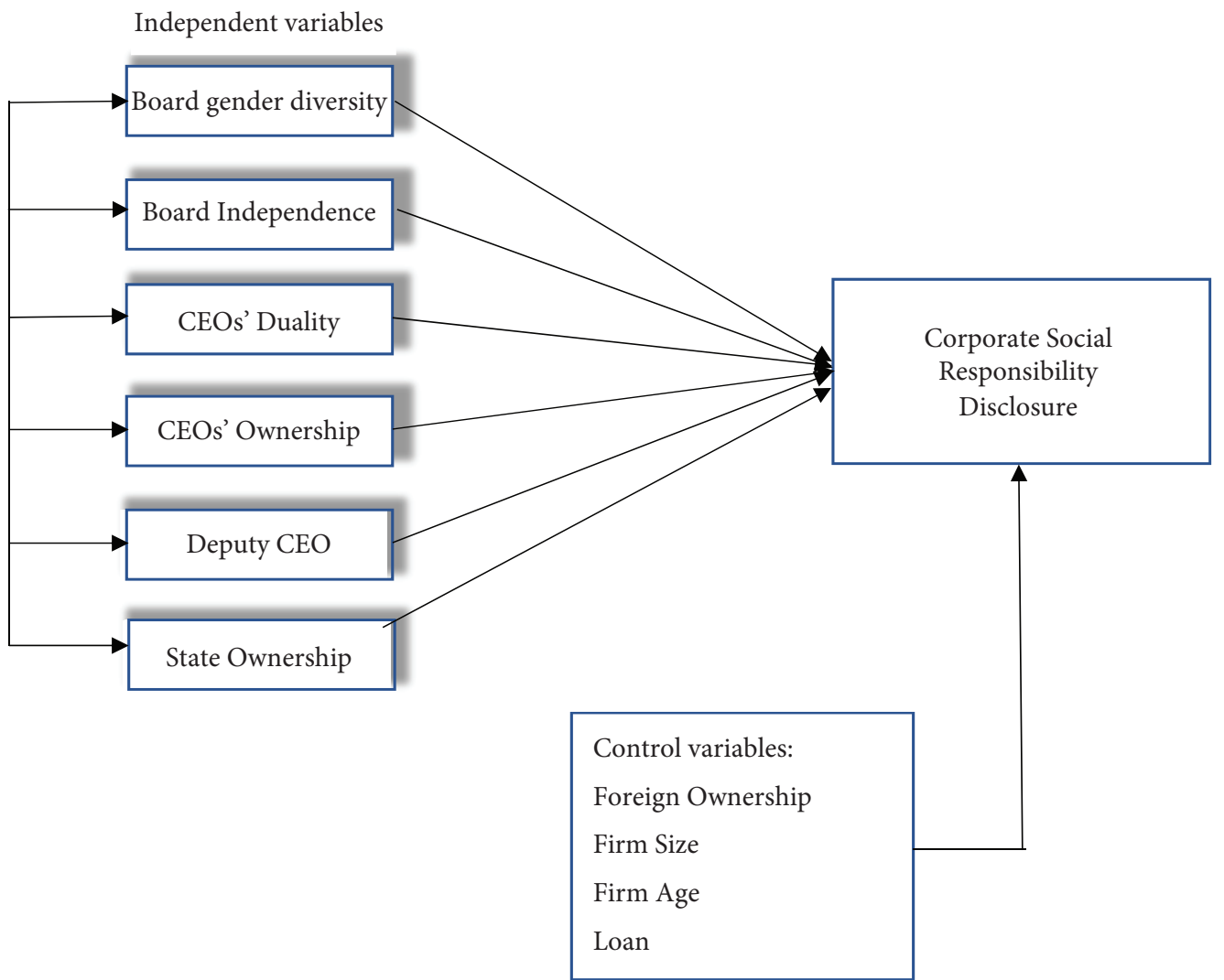

Figure 1. Conceptual model: Relationship between CEO power, board diversity, state ownership, factors affecting CSR disclosure, and CSR disclosure 
to higher CSR performance. Hudson and Miller (2005) argued that women are more conscious to CSR related field, particularly with environmental field. More precisely, the study, undertaken by del Mar Alonso-Almeida et al. (2015), found that the leadership style of female directors promotes CSR. This is because female directors tend to show a participatory decision-making style and teamwork-oriented tendency. Thus, they can consider and stabilize the wide needs of stakeholders surrounding companies. In another study, empirical results from the study of Zhang et al. (2013) also showed that there is a positive relation between the presence of women on the board of governors and the performance of CSR publication. The authors suggested that female directors turn to have certain mental aspect that can lead them become more conscious to the demands of individual stakeholders and thus increase their profile.

Based on this reasoning, our research question is:

Hypothesis 1: The rate of female directors on the BOD leads to a positive result on CSR publication.

\section{Board independence}

Board independence is one of factors which are most often used in studies to define the characteristics of board diversity. The board's independence is not only conducive to the adaption of sustainable indicators but also positively linked to the status of publication quality of firms, the promotion of the system of reporting and transparent publication (Barros et al., 2013). There are two types of director on board: inside directors whose responsibility is to make management decisions, and non- executive external directors who provide independent views on the strategy and performance of companies' activities. Due to the independence with external directors, empirical researches suggest that the number of non- managing directors (independent directors) impacts positively to the degree of responsible behavior and transparency in firms. Moreover, non- executive directors also bring great value and an outside perspective to advance company performance. Besides, these external directors are generally be emotional to the needs of all stakeholders, so they are willing to satisfy social desire and thus encourage companies to be more committed to social and environmental sustainability (Ibrahim \& Angelidis, 1995).

Many previous studies showed that there is a positive linkage between the percentage of external directors and the degree of CSR publication quality. There are several possible explanations for this finding. Independent boards intimately involved in reporting on CSR to promote the interests of stakeholders. These directors may require further information which is showed in the company's reports and thus encourage top management team to provide and communicate more information. The research finding, undertaken by Herda et al. (2014), also pointed out that an increasing rate of independent board members tends to align with the interest of stakeholders and is highly likely to provide a higher condition and transparency of sustainability report. This study also indicated that the presence of external board directors plays a powerful function to advance CSR publication quality and quantity.

Therefore, found on reasons above, the research question is:

Hypothesis 2. The proportion of external directors is positively linked with CSR publication.

\section{CEOs' duality}

According to Malik et al. (2020), the concentration of decision power is one of the matters of corporate governance. A central question for the decision power is whether one staff should hold both the status of Chairman and CEO of the company or not. Duality means that a person who is CEO and Chairman at the same time is highly likely to prioritize personal benefit at the cost of stakeholders.

Rooting from agency theory, the concentration of roles will put the performance of the board members at uncertainty because management policies and decisions have to be checked and controlled under the segregation of role between CEO and chairman (Malik et al., 2020). $\mathrm{Al}$ Mamun et al. (2013) also suggested that this phenomenon turns to decrease the freedom level of the board, leading to the reduce of board monitoring's efficiency and effectiveness. However, proponents of stewardship theory demand the concentration of decision power in CEO (Malik et al., 2020). The proponents of this view support the opinion that the concentration of role brings a cooperative command structure and consistent leadership and thus contributes the efficiency of decision, implements rapidly operational decisions and advances corporate performance.

Nevertheless, not all companies, merging the duties of executive and Chairman, is a governance failure and not all companies separating the roles of executive and Chairman is a positive governance model. This argument is approved by Malik et al. (2020) who argued that the role separation also encourages the quality of disclosure and reduces the risk of bias disclosure.

Based on the above set of arguments, we propose that CEO duality impact positively or negatively on CSR disclosure.

Hypothesis 3: CEOs duality impacts positively or negatively on CSR disclosure.

\section{CEO ownership}

Another phenomenon of corporate governance that attracts the interest of corporate finance scholars is managerial ownership. Drawing from agency theory, studies suggested that firms can raise the alignment of CEOs' incentives with those of other shareholders by giving them a proportion of firm's shares (Jensen \& Meckling, 1979) the theory of property rights and the theory of finance to develop a theory of the ownership structure of the firm. We define the concept of agency costs, show its relationship to the separation and control issue, investigate the nature 
of the agency costs generated by the existence of debt and outside equity, demonstrate who bears these costs and why, and investigate the Pareto optimality of their existence. We also provide a new definition of the firm, and show how our analysis of the factors influencing the creation and issuance of debt and equity claims is a special case of the supply side of the completeness of markets problem. The directors of such joint-stock companies, however, being the managers rather of other people's money than of their own, it cannot well be expected, that they should watch over it with the same anxious vigilance with which the partners in a private copartnery frequently watch over their own. Like the stewards of a rich man, they are apt to consider attention to small matters as not for their master's honour, and very easily give themselves a dispensation from having it. Negligence and profusion, therefore, must always prevail, more or less, in the management of the affairs of such a company. Adam Smith, The Wealth of Nations, 1776, Cannan Edition (Modern Library, New York, 1937. Nevertheless, increased managers' ownership may result in CEOs becoming entrenched and dominating firms' strategic decision making. Thus, hubris may lead managers to inappropriately assess corporate social performance. In another study, Malik et al. (2020) argued that such firms do not consider social performance because they suppose that the cost of investing and disclosing social activities is higher than the benefits. In line with their expectations, Garcia-Torea et al. (2017) argued that management holding has a negative result on the degree of voluntary publication. The research question is:

Hypothesis 4: The nexus between the percentage of CEOs' ownership and CSR disclosure is negative.

\section{Deputy CEO and CEO power}

Little is perceived about deputy CEO, and the impact of it on $\mathrm{CEO}$ power is uncertain yet. In addition, there are not too many academic studies relating to deputy CEOs and the role of them. According to job descriptions, the primary responsibility of Deputy CEO is to assist CEO "with managing and directing the organization towards its strategic objectives, based on the entity's vision, mission statement and goals". We can suppose that the existence of deputy CEOs in the BOD can disintegrate the power concentrated on the hand of CEOs. As pointed out by Sheikh (2019), most of empirical research findings suggest that executive power is negatively associated to CSR. Thus, we argue following hypothesis:

Hypothesis 5: The nexus between the quantity of deputy CEOs and the status of CSR disclosures is positive.

\section{State ownership}

State holding is another important characteristic in the Vietnamese corporate sector, especially in privatized firms. A state-owned company can be expected to be more politically sensitive as the operation of these companies receive the higher consideration of authorities. This is because the government's ownership indirectly means that the company belongs to the general public. This type of company can, therefore, involve in more socially responsible activities and thereby increase the publicity of social activities in order to legitimize its existence.

Ghazali (2007) even among the larger and actively traded stocks in Malaysia, there is considerable variability in the amount of social activities disclosed in corporate annual reports. Results from multiple regression analysis show that, consistent with expectations, companies in which the directors hold a higher proportion of equity shares (owner-managed companies illustrated that firms in which the state holds a substantial amount of share discloses higher CSR information quality than other firms in their annual reports. With the much greater impact of political interference on the behavior of companies, the higher level of perceived government effect on corporate activity is predicted to drive to more considerable management efforts to meet government expectations. The government, the majority shareholder of state-owned companies, has reason to divert capital to achieve the goal of social balance (Bai et al., 2006), contributing to improving the CSR. The high level of government ownership encourage CEOs to obtain non-financial governmental objectives such as the development of infrastructure, the resolution of fiscal and unemployment difficulties; as a result, these social or political goals put constrain on companies to attempt CSR. Taking into consideration of listed Chinese firms, being similar to Vietnam where the government is a substantial shareholder in essential industries and struggle for political resources is exacerbating, $\mathrm{Xu}$ and Zeng (2016) found that corporates in which the State is a main shareholder are positively associated with CSR indicators including the governance, social and environmental scores. Therefore, a company in which the State is a significant shareholder is expected to reveal higher quality of CSR disclosure in its annual reports. Accordingly, we come up with our hypothesis as follows:

Hypothesis 6: The nexus between the percentage of state ownership and CSR disclosure is positive.

\section{Methodology}

\section{Sample and data collection}

The sample of this research contains of 191 Vietnamese listed firms at the Hanoi Stock Exchange (HNX) (we excluded companies which do not have annual reports or miss data in corporate governance indicators). The sample of this study was taken from listed firms in the period between 2014 and 2016, chosen from various industries including Commerce (26.18\%), Construction (21.99\%), Exploitation (13.09\%), Manufacturing (23.56\%) and Service $(15.18 \%)$ (Table 1$)$.

BOD data on board and CEO factors and ownership structure were obtained from firm's annual reports available in the HNX database and the Hanoi Stock Exchange $\mathrm{R} \& \mathrm{D}$ department. 
CSR disclosure data was taken from annual, standalone reports, and firm websites provided by the R\&D department of the Hanoi Stock Exchange. We used a proxy of perspectives to explain differences of CSR disclosure among listed companies in Vietnamese listed firms. Companies with high scores present high CSR disclosure.

Table 1. Sample description

\begin{tabular}{|l|c|c|}
\hline \multicolumn{1}{|c|}{ Sector } & N & Percentage \\
\hline Commerce & 50 & $26.18 \%$ \\
\hline Construction & 42 & $21.99 \%$ \\
\hline Exploitation & 25 & $13.09 \%$ \\
\hline Manufacturing & 45 & $23.56 \%$ \\
\hline Service & 29 & $15.18 \%$ \\
\hline Sum & 191 & $100 \%$ \\
\hline
\end{tabular}

The definition of CSR disclosure among the authors is heterogeneous and the disclosure of the CSR is defined in various ways. CSR measurement causes many problems due to its "multidimensional nature". To undertake this research, we established an inclusive CSR disclosure index (see Table 2). This included five CSR aspects and 20 individual CSR criteria (5 environment indicators, 4 energy indicators, 3 product quality indicators, 5 employment relation indicators, 3 society involvement indicators) that present a whole view of a company's CSR and follow Circular 155/2015/TT, on 06/10/2015 by Vietnamese Ministry of Finance. Each item is marked 1 if presented, and zero if not.

The final CSR disclosure Score was detemined as follows:

$$
\mathrm{CSRDL}=\sum_{j=1}^{e} \frac{e j}{e},
$$

where: CSRDL $=$ CSR Disclosure index; $e j=$ Number of elements that company disclose ( 1 if publication item is seen, and 0 if not seen); $e=$ The highest quantity of elements that a firm can present (maximum is 20).

\section{Econometric model}

The regression equation in this research is:

$$
\begin{aligned}
& \text { CSRDLit }=\beta 0+\beta 1 \text { GENDit }+\beta 2 \text { INDit }+ \\
& \beta 3 \text { DUAit }+\beta 4 \text { CEOOWNit }+\beta 5 \text { DEPit }+ \\
& \beta 6 \text { STATEOWNit }+\beta 7 \text { FOREit }+\beta 8 \text { SIZEit }+ \\
& \text { AGEit }+ \text { LOAit }+\varepsilon i t .
\end{aligned}
$$

\begin{tabular}{|c|c|c|}
\hline Perspectives & No. & Sub-categories \\
\hline \multirow{5}{*}{ Environment } & 1 & $\begin{array}{l}\text { Specify the environmental risks possibly impacting on the production and corporate activities or the } \\
\text { awareness of the corporate's goal }\end{array}$ \\
\hline & 2 & Proportion and a total level of water recycled and reused \\
\hline & 3 & An inspection relating the environmental problems (water and energy consumption, emissions...) \\
\hline & 4 & Quantity of times the business is punished due to fail to satisfy with regulations about environment \\
\hline & 5 & The total fined due to fail to satisfy with regulations about environment \\
\hline \multirow{4}{*}{ Energy } & 6 & Energy consumption - directly and indirectly \\
\hline & 7 & Energy savings through indicators of efficiently spending energy \\
\hline & 8 & Water supplied and quantity of water spent \\
\hline & 9 & Energy savings report of efficiently using energy \\
\hline \multirow{3}{*}{$\begin{array}{l}\text { Product } \\
\text { quality }\end{array}$} & 10 & $\begin{array}{l}\text { Providing goods and services to conserve energy or utilize sustainable energy; reported on energy saving } \\
\text { initiatives }\end{array}$ \\
\hline & 11 & $\begin{array}{l}\text { The total quantity of unprocessed materials needed for the assembling and packaging of the goods and } \\
\text { services of the business annually }\end{array}$ \\
\hline & 12 & The rate of materials recycled to make goods and services of the business \\
\hline \multirow{5}{*}{$\begin{array}{l}\text { Employment } \\
\text { relation }\end{array}$} & 13 & The number of workers, average wages of employees \\
\hline & 14 & Labour rules to ensure the health, safety, and benefit of employees \\
\hline & 15 & The average amount of coaching hours annually, coresponding to the employee and classified employee \\
\hline & 16 & $\begin{array}{l}\text { Continuously develop skills and learning programs to assist employees in securing employment and career } \\
\text { development }\end{array}$ \\
\hline & 17 & A review concerning the problems of employees \\
\hline \multirow{3}{*}{$\begin{array}{l}\text { Society } \\
\text { involvement }\end{array}$} & 18 & Corporate objectives concerning Corporate society and society Sustainability \\
\hline & 19 & The society growth and other society growth activities, consisting of financial assistance to society service \\
\hline & 20 & A review relating business responsibility towards the regional society \\
\hline
\end{tabular}

Table 3 presents the definition and measurement of variables in the model.

Table 2. Elements of CSR disclosure 
Table 3. A summary of variables

\begin{tabular}{|c|c|c|}
\hline Variable & $\begin{array}{c}\text { Full variable } \\
\text { name }\end{array}$ & Measurement \\
\hline GEND & $\begin{array}{l}\text { Gender } \\
\text { diversity }\end{array}$ & $\begin{array}{l}\text { Percentage of female directors } \\
\text { on govern board }\end{array}$ \\
\hline IND & $\begin{array}{l}\text { Independent } \\
\text { directors }\end{array}$ & $\begin{array}{l}\text { Ratio of independent (non- } \\
\text { executive) directors on the } \\
\text { govern board }\end{array}$ \\
\hline DUA & $\begin{array}{l}\text { Executive } \\
\text { duality }\end{array}$ & $\begin{array}{l}\text { A dummy variable with the } \\
\text { value equaling to } 1 \text { if the CEO } \\
\text { is also the Chair, and } 0 \text { if not }\end{array}$ \\
\hline CEOOWN & $\begin{array}{l}\text { CEO } \\
\text { ownership }\end{array}$ & Percentage of CEO ownership \\
\hline DEP & Deputy CEO & Number of deputy CEO \\
\hline STATEOWN & \begin{tabular}{|l} 
State \\
ownership
\end{tabular} & Ratio of state ownership \\
\hline FORE & $\begin{array}{l}\text { Foreign } \\
\text { ownership }\end{array}$ & Ratio of foreign ownership \\
\hline SIZE & Firm size & Logrit of total asset \\
\hline AGE & Firm age & The age of firm \\
\hline LOA & Loan & Loan value \\
\hline$\varepsilon$ & Error part & \\
\hline $\mathrm{t}$ & \multicolumn{2}{|c|}{ Time aspect (year) } \\
\hline i & \multicolumn{2}{|c|}{ Cross-section aspect (firm observations) } \\
\hline
\end{tabular}

Control variables: FORE, SIZE, AGE and LOA are taken due to the appropriation with precious research (Malik et al., 2020; Katmon et al., 2019)

\section{Results and analysis}

Table 4 describes the summarise of statistics for both explanatory and independent variables. This table consists of indicators: observation, minimum, maximum mean and standard deviation. The mean of the CSR publication index for the whole population is at 1,370 , and the range is from 0,400 to maximum 5,000 . The proportion of women in BOD has a range between 0 and $80 \%$, showing that existing firms with homogeneous board gender diversity ( $100 \%$ is male director), while some companies have $80 \%$ female director on board. The mean value is quite low (12.7\%) but still higher than that in some other developing countries like Malaysia: 8\% (Katmon et al., 2019). Concerning board independence, independent directors accounted for the rate of total directors with the mean value of $59.5 \%$, which are slightly higher than (Kabir \& Thai, 2017) who reported that the mean for non-executive director proportion was $56 \%$ in the period from 2008 to 2013. Among the selected firms, the Chair performs the functions of CEO, which accounts for $29.3 \%$ of total firms, whereas, $70.7 \%$ of the total firms' power does not concentrate on the hand of CEO (the responsible division between $\mathrm{CEO}$ and chair). This proportion of CEO duality is at medium level (mean: 29.3\%), which is lower than that figure in developed countries like the United State (50\%) (Malik et al., 2020) but higher than it in other developing countries like Pakistan (17\%) (Malik et al., 2020). In term of CEO ownership, $5.056 \%$ is

Table 4. The summarise of statistics

\begin{tabular}{|l|c|c|c|c|c|}
\hline \multicolumn{1}{|c|}{ Variable } & Observation & Mean & Minimum & Maximum & Standard deviation \\
\hline CSRDL & 573 & 1.370 & 0.400 & 5.000 & 0.942 \\
\hline GEND(\%) & 573 & .127 & 0 & 0.8 & .158 \\
\hline IND(\%) & 573 & .595 & 0 & 1.0 & .184 \\
\hline DUA(\%) & 573 & 0.293 & 0 & 50.448 & 8.282 \\
\hline CEOOWN(\%) & 573 & 5.056 & 0 & 82.95 & 1.493 \\
\hline DEP & 573 & 3.033 & 0 & 55.57 & 25.100 \\
\hline STATEOWN(\%) & 573 & 24.526 & 0 & 30.90 & 8.884 \\
\hline FORE(\%) & 573 & 4.196 & 23.28 & 4.12 & 1.349 \\
\hline SIZE & 573 & 3.073 & 1.79 & 0.72 & .571 \\
\hline AGE & 573 & .201 & 0 & 0 \\
\hline LOA & 573 & & 0 & 187 \\
\hline
\end{tabular}

Table 5. The summarise of statistics for components of CSR disclosure

\begin{tabular}{|l|c|c|c|c|c|}
\hline \multicolumn{1}{|c|}{ Variable } & Observation & Mean & Minimum & Maximum & Standard Deviation \\
\hline Environment & 573 & 2.488 & 0 & 5 & .756 \\
\hline Energy & 573 & .260 & 0 & 4 & .768 \\
\hline Product quality & 573 & .218 & 0 & 3 & .590 \\
\hline Employment relation & 573 & 1.916 & 0 & 5 & 1.594 \\
\hline Society involvement & 573 & 1.054 & 0 & 3 & 1.196 \\
\hline
\end{tabular}


Table 6. Correlation statistics for variable

\begin{tabular}{|l|c|c|c|c|c|c|c|c|c|c|c|}
\hline & 1 & 2 & 3 & 4 & 5 & 6 & 7 & 8 & 9 & 10 & 11 \\
\hline CSRDL & 1 & & & & & & & & & & \\
\hline GEND & 0.008 & 1 & & & & & & & & & \\
\hline IND & -0.012 & 0.018 & 1 & & & & & & & & \\
\hline DUA & 0.032 & 0.044 & $-0.264^{* *}$ & 1 & & & & & & & \\
\hline CEOOWN & -0.076 & $0.099^{*}$ & $-0.290^{* *}$ & $0.378^{* *}$ & 1 & & & & & & \\
\hline DEP & $0.221^{* *}$ & -0.038 & $-0.178^{* *}$ & $-0.106^{*}$ & $-0.125^{* *}$ & 1 & & & & & \\
\hline STATEOWN & $-0.174^{* *}$ & $-0.168^{* *}$ & -0.059 & $-0.186^{* *}$ & $-0.091^{*}$ & $0.089^{*}$ & 1 & & & & \\
\hline FORE & -0.067 & 0.047 & -0.025 & $0.089^{*}$ & 0.053 & -0.066 & 0.004 & 1 & & & \\
\hline SIZE & $0.160^{* *}$ & $-0.137^{* *}$ & $0.134^{* *}$ & $-0.154^{* *}$ & $-0.113^{* *}$ & $0.548^{* *}$ & $0.114^{* *}$ & $-0.087^{*}$ & 1 & & \\
\hline AGE & -0.024 & 0.049 & $-0.158^{* *}$ & -0.003 & 0.012 & $0.248^{* *}$ & $0.266^{* *}$ & $-0.101^{*}$ & $0.112^{* *}$ & 1 & \\
\hline LOA & $0.128^{* *}$ & $-0.109^{* *}$ & -0.009 & -0.049 & 0.020 & $0.210^{* *}$ & 0.016 & $-0.135^{* *}$ & $0.478^{* *}$ & 0.022 & 1 \\
\hline
\end{tabular}

Notes: ${ }^{\star \star *}$ : $0.01 \mathrm{Sig} ;{ }^{\star \star}$ : $0.05 \mathrm{Sig} ;{ }^{\star}$ : 0.1 Sig.

the mean that a CEO holds a stake in the company. The mean of state ownership is at $24.526 \%$, and the range is from $0 \%$ to $82.95 \%$ over the period 2007 to 2012 for Vietnamese listed firms.

Regarding CSR categories, Table 5 presents that environment theme is the most disclosed theme (mean: 2.488), followed by employment relation, with a mean of 1.916. Society involvement disclosure is 1.054 ; energy and product quality has the lowest scores with 0.26 and 0.218 , respectively.

Before conducting a regression analysis, we undertook the Pearson correlation analysis. Corporate social responsibility disclosure score (CSRDL) was correlated with the number of deputy-CEO (DEP), state ownership percentage (STATEOWN), firm size (SIZE) and loan (LOA) at the 0.01 level (Table 6). Table 7 describes the results of the variance inflation factor and tolerance, checking the difficulty of multicollinearity. The variance inflation factor value does not exceed 10, and the tolerance value is not below 0.1, agreeing with the suggestion of Field (2005), which indicates the non-existence of multicollinearity.

Table 7. Multi-collinearity

\begin{tabular}{|l|c|c|}
\hline \multicolumn{1}{|c|}{ Variable } & $\begin{array}{c}\text { Variance Inflation } \\
\text { Factor }\end{array}$ & Tolerance \\
\hline GEND & 1.08 & 0.929 \\
\hline IND & 1.34 & 0.746 \\
\hline DUA & 1.71 & 0.583 \\
\hline CEOOWN & 1.27 & 0.785 \\
\hline DEP & 1.71 & 0.583 \\
\hline STATEOWN & 1.18 & 0.850 \\
\hline FORE & 1.04 & 0.959 \\
\hline SIZE & 2.01 & 0.498 \\
\hline AGE & 1.18 & 0.844 \\
\hline LOA & 1.35 & 0.741 \\
\hline
\end{tabular}

To test six hypotheses, multiple regression analysis with a panel data is used. Table 8 illustrates the regression model results for three regression models: pooled OLS, fixed-effects model (FEM) and random-effects model (REM). Furthermore, we analysed a modified Wald test of group-wise heteroskedasticity, which reported the existence of heteroskedasticity in our population $(\mathrm{p}<0.01)$ as well as Wooldridge test for autocorrelation in panel data $(\mathrm{p}<0.01)$ and Pesaran's test for cross-section dimension $(\mathrm{p}<0.01)$. Finally, the pooled OLS model with Driscoll and Kraay standard errors was used to defend the errors of the fix effect regression model.

In order to solve heteroscedasticity and autocorrelation problems, we applied the robust standard errors for the FEM analysis. As can be found in Table 8, the R2 value for the three models: pooled OLS, REM and FEM (robust) are presented.

Determined from the Testify the Breusch and Pagan Lagrangian multiplier test and Hausman specification test, the authors applied the fix effect regression model as the best and suitable model for the sample. Indeed, Table 7 shows the $\mathrm{p}$-value of the LM test $(\mathrm{p}<0.01)$, indicating that the REM is more efficient than the pooled OLS model. Regarding the value of the Hausman test $(\mathrm{p}<0.01)$, this result showed that FEM (robust) is more suitable than REM in this research.

Regarding to $\mathrm{H} 1$, predicting that the rate of directors who are female on the BOD has a positive influence on CSR disclosure, was rejected. As shown in Table 8, there is a moderately significant and negative linkage between the rate of female directors and CSR publication $(\beta=-0.32$, $\mathrm{p}<0.1)$.

Regarding to $\mathrm{H} 2$, which stated that the rate of independent directors is positively linked to CSR publication, it was also rejected. The outcomes illustrated that the rate of external directors has an insignificant result on CSR publication. Similarly, drawing from the results of table 8 , the coefficient of CEO duality and CEO holding variables are not significant, indicating that the 
Table 8. Regression results

\begin{tabular}{|c|c|c|c|c|c|c|}
\hline \multirow{2}{*}{ Variable } & \multicolumn{2}{|c|}{ Pooled OLS } & \multicolumn{2}{|c|}{ RE model } & \multicolumn{2}{|c|}{ FE model (robust) } \\
\hline & Standard Error & Coefficient & Standard Error & Coefficient & Standard Error & Coefficient \\
\hline GEND & 0.252 & -0.154 & 0.174 & -0.245 & 0.181 & $-0.320^{*}$ \\
\hline IND & 0.239 & -0.202 & 0.151 & 0.150 & 0.181 & 0.174 \\
\hline DUA & 0.092 & 0.083 & 0.058 & -0.059 & 0.072 & -0.085 \\
\hline CEOOWN & 0.005 & -0.005 & 0.002 & 0.002 & 0.003 & 0.002 \\
\hline DEP & 0.035 & $0.093^{* * *}$ & 0.021 & $0.053^{* *}$ & 0.025 & $0.049^{* *}$ \\
\hline STATEOWN & 0.001 & $-0.006^{* * *}$ & 0.001 & 0.001 & 0.001 & $0.002^{\star * *}$ \\
\hline FORE & 0.004 & -0.003 & 0.002 & -0.002 & 0.004 & -0.002 \\
\hline SIZE & 0.039 & 0.051 & 0.046 & 0.056 & 0.108 & -0.012 \\
\hline AGE & 0.072 & -0.061 & 0.113 & -0.091 & 0.566 & 0.547 \\
\hline LOA & 0.239 & 0.369 & 0.189 & $-0.356^{\star}$ & 0.214 & $-0.502^{\star *}$ \\
\hline Year Dummies & \multicolumn{2}{|c|}{ In the model } & \multicolumn{2}{|c|}{ In the model } & \multicolumn{2}{|c|}{ In the model } \\
\hline $\begin{array}{l}\text { Industry } \\
\text { Dummies }\end{array}$ & \multicolumn{2}{|c|}{ In the model } & \multicolumn{2}{|c|}{ In the model } & \multicolumn{2}{|c|}{ In the model } \\
\hline Constant & 0.967 & 0.420 & 1,217 & 0.204 & 0,165 & $0.449^{* * *}$ \\
\hline $\begin{array}{l}\text { No. of } \\
\text { observations }\end{array}$ & \multicolumn{2}{|c|}{573} & \multicolumn{2}{|c|}{573} & \multicolumn{2}{|c|}{573} \\
\hline Adjusted R2 & \multicolumn{2}{|c|}{0.1427} & \multicolumn{2}{|c|}{0.0758} & \multicolumn{2}{|c|}{0.0009} \\
\hline
\end{tabular}

Notes: ${ }^{\star * *}: 0.01 \mathrm{Sig} ;{ }^{* *}: 0.05 \mathrm{Sig} ;{ }^{*}: 0.1 \mathrm{Sig}$.

influence of executive duality and executive ownership on CSR disclosure is insignificant, hence rejecting hypothesis 3 and 4 .

Hypothesis 5 predicted that there is a positive linkage between the quantity of deputy CEOs and the status of CSR publication. Our hypothesis proved correctly because the number of deputy CEOs was positively correlated to CSR disclosure degree $(\beta=0.049, \mathrm{p}<0.05)$.

Hypothesis 6 stated that the linkage between the rate of state holding and CSR disclosure is positive. This hypothesis received significant support as the percentage of state ownership was positively significant to CSR disclosure level $(\beta=0.002, \mathrm{p}<0.05)$.

The findings are summarized in Table 9 below.

Table 9. A summary of findings

\begin{tabular}{|l|l|}
\hline \multicolumn{1}{|c|}{ Hypotheses } & \multicolumn{1}{c|}{ Results } \\
\hline $\begin{array}{l}\text { H1: Percentage of female directors } \rightarrow \\
\text { CSR disclosure }(+)\end{array}$ & $\begin{array}{l}\text { Not support } \\
\text { (negative) }\end{array}$ \\
\hline $\begin{array}{l}\text { H2: Percentage of independent directors } \\
\rightarrow \text { CSR disclosure }(+)\end{array}$ & $\begin{array}{l}\text { Not support } \\
\text { (insignificant) }\end{array}$ \\
\hline H3: CEO duality $\rightarrow$ CSR disclosure (+/-) & $\begin{array}{l}\text { Not support } \\
\text { (insignificant) }\end{array}$ \\
\hline $\begin{array}{l}\text { H4: CEO ownership } \rightarrow \text { CSR disclosure } \\
(-)\end{array}$ & $\begin{array}{l}\text { Not support } \\
\text { (insignificant) }\end{array}$ \\
\hline $\begin{array}{l}\text { H5: Number of deputy CEOs } \rightarrow \text { CSR } \\
\text { disclosure }(+)\end{array}$ & Support \\
\hline $\begin{array}{l}\text { H6: State ownership } \rightarrow \text { CSR disclosure } \\
(+)\end{array}$ & Support \\
\hline
\end{tabular}

\section{Discussion}

This research has a goal to assess the empirical association between gender diversity, CEO power, state holding and the degree of CSR disclosure. Taking the sample of firms from 2014 to 2016, the results of our regression analysis shows significant relationships.

Regarding board gender diversity, our findings report the nonappearance of positive relation between the variable and CSR publication. Although this result is inconsistence with the empirical results of previous studies, it coincides with the results taken from the research of Muttakin et al. (2018), which showed a negative relationship. As noted by the authors, this result can be explained by the consequence of female managers who lack education and expertise level. Additionally, the authors provide empirical evidence that family-owned firms, which have more women on the board of governors, turn to impact negatively on the degree of CSR disclosure quality in the firms. It can be explained that due to family - value orientation, female directors are under little pressure to engage in a wider perspective regarding to CSR-related activities (Muttakin et al., 2018). In the context of Vietnam, according to Kelly (2011), while there is a balanced number of men and women graduating from the same undergraduate level, women only consist of $30.5 \%$ of Master degrees and $17.1 \%$ of $\mathrm{PhD}$ degrees in total. Moreover, family businesses are quite popular in Vietnam, making up around 37 percent of total businesses listed on Ha Noi and Ho Chi Minh stock exchange, subtracting firms in financial sector (Nguyen, 2018). To sum up, the lower education level of 
female directors, compared to male colleagues, and the high proportion of family firms in Vietnam can explain why female director ratio on the BOD has a positive burden on CSR publication.

An important result of this research is the rejection of hypothesis 2. Our empirical results reject our proposed hypothesis and what previous literature suggests. This result may be due to the function and responsibility of independent directors in different countries. In Vietnam, the independent director in BOD discontinue to be an essential characteristic in the CSR disclosure within the situation of the state-owned privatization. Many Vietnamese companies cannot hold annual shareholders' meetings because of the insufficient shareholders and members of BOD, which means that non-manage directors do not have a vital role in protecting the right of the shareholders (A. Dang et al., 2018). Thus, they may not be impacted by the right of stakeholders.

Contrasting with the previous literature, the hypothesis related to the CEO duality was rejected. This study showed that the duality is not a main variable in the CSR disclosure, more specifically, CEO duality is seen to be negative but it is insignificant in situation of Vietnamese listed companies. This conclusion is similar with previous study of Malik et al. (2020).

The insignificant impact of executives' ownership over the CSR disclosure is inconsistent with our hypothesis. This empirical finding aligns with the study undertaken by Oh et al. (2016) who argued that we should also assess the difference of strategic decisions (for example: advancing financial performance) and operational problems such as making acquisition processes more socially answerable, which firms follow, instead of basing solely on CEO factors and incentives to shape CSR. Thus, the reason for this result can be the pressure of financial performance, which surpasses social and non-economic outcome in Vietnamese firms. Moreover, the ratio of CEOs' ownership is relatively low at $5.056 \%$ (mean value), $0 \%$ (min value) and $50.448 \%$ (max value) so, it may be that this relatively small percentage does not show a significant impact on CSR disclosure.

Turning to deputy CEO, results show the agreement with the first hypothesis, which argues that there is a positive linkage between the quantity of deputy CEOs and the degree of CSR publication. These results are in line with our proposed causality. The higher the number of deputy CEOs in the firm, the lower the level of concentration power in the hand of CEOs, which can enhance disclosure quality (Sheikh, 2019).

Previous research indicated that state share could present a positive effect on CSR publication, in our result, this characteristic also has a significant impact. This result can be explained by the context of privatization of state-own enterprises (SOEs) in Vietnam from the last two decades. According to the Steering Committee for Enterprise Renovation and Development of Vietnam, over the past 20 years, about $92 \%$ of total SOEs have been equitized, but only about $10 \%$ of the state capital has been replaced by other resources. Mohamed Adnan et al. (2018) argued that if the government owns the major percentage of firms' ownership, these firms are highly likely to enhance the quality of CSR reporting. Similarly, previous studies also illustrated that state ownership is positive significant related to CSR disclosure (Ghazali, 2007) even among the larger and actively traded stocks in Malaysia, there is considerable variability in the amount of social activities disclosed in corporate annual reports. Results from multiple regression analysis show that, consistent with expectations, companies in which the directors hold a higher proportion of equity shares (owner-managed companies.

\section{Conclusions}

This research has studied the effect of board diversity, executive power and state holding on Vietnamese firms CSR disclosure. Looking into data of 191 firms from six categories listed at the Hanoi Stock Exchange for the duration 2014 to 2016, the authors analyse the assumptions argued in this paper. Our findings give observational evidence for the significant effect of the rate of non-executive directors, CEOs' duality and the quantity of deputy CEOs. In addition, percentage of female directors, CEOs' ownership and state ownership is found to be insignificant.

Some practical implications can be acquired from this study. Because corporate governance and CEO are the essential characteristics in understanding the firm's process and its strategic decisions, findings of this study might provide empirical evidence for Vietnamese firms, stakeholders and policymakers. For instance, if Vietnamese firms want to follow positively CSR disclosure performance, they should employ a higher number of deputy CEOs, a lower number of female directors and increase the percentage of state ownership. Other emerging countries with similar economic situation and regulation can also take benefit from our findings. Regarding theory implications, this research provides valuable insight to the literature of board diversity, CEO power, state ownership and listed firms' CSR disclosure, which adds literature to resource - based view theory and agency theory.

There are some limitation from this paper. First, this study lacks generalization because the sample from one country is chosen, which restricts its generalization. Second, other board diversity and CEO power factors such as CEO tenure, family CEO status, educational background diversity and age diversity were not included in this study. Follow-up studies should incorporate these characteristics into consideration. We also admit that assessing CSR disclosure performance by assigning scores for CSR items, which can be considered as qualitative information, can be subjective and bias in some cases.

\section{Acknowledgements}

We thank Prof. Prasad Padmanabhan (St. Mary's University) and Prof. Francois Labelle (University of Quebec at Trois-Rieveres) for their comments on the manuscript. 


\section{Disclosure statement}

We do not have any competing financial, professional, or personal interests from other parties.

\section{References}

Al Mamun, A., Rafique Yasser, Q., \& Ashikur Rahman, M. (2013). A discussion of the suitability of only one vs more than one theory for depicting corporate governance. Modern Economy, 04(01), 37-48. https://doi.org/10.4236/me.2013.41005

Bai, C. E. N., Lu, J., \& Tao, Z. (2006). The multitask theory of state enterprise reform: Empirical evidence from China. American Economic Review, 96(2), 353-357. https://doi.org/10.1257/000282806777212125

Barros, C. P., Boubaker, S., \& Hamrouni, A. (2013). Corporate governance and voluntary disclosure in France. Journal of Applied Business Research, 29(2), 561-578.

https://doi.org/10.19030/jabr.v29i2.7657

Ben-Amar, W., Chang, M., \& McIlkenny, P. (2017). Board gender diversity and corporate response to sustainability initiatives: evidence from the Carbon Disclosure Project. Journal of Business Ethics, 142(2), 369-383.

https://doi.org/10.1007/s10551-015-2759-1

Dang A., R., Houanti, L., Le, N. T., \& Vu, M. C. (2018). Does corporate governance influence firm performance? Quantile regression evidence from a transactional economy. Applied Economics Letters, 25(14), 984-988. https://doi.org/10.1080/13504851.2017.1390309

del Mar Alonso-Almeida, M., Perramon, J., \& Bagur, L. (2015). Women managers and corporate social responsibility (CSR) in Spain: Perceptions and drivers. Women's Studies International Forum, 50, 47-56. https://doi.org/10.1016/j.wsif.2015.02.007

Fama, E. F., \& Jensen, M. C. (1983). Agency problems and residual claims. The Journal of Law and Economics, 26(2), 327-349. https://doi.org/10.1086/467038

Ferrero-Ferrero, I., Fernández-Izquierdo, M. Á., \& MuñozTorres, M. J. (2015). Integrating sustainability into corporate governance: an empirical study on board diversity. Corporate Social Responsibility and Environmental Management, 22(4), 193-207. https://doi.org/10.1002/csr.1333

Field, A. (2005). Discovering statistics using SPSS (2nd ed.). SAGE Publications.

Garcia-Torea, N., Fernandez-Feijoo, B., \& de la Cuesta-González, M. (2017). La influencia de la estructura de propiedad en la transparencia de la información de RSC: evidencia del caso Español. Revista Espanola de Financiacion y Contabilidad, 46(3), 249-271.

https://doi.org/10.1080/02102412.2016.1267451

Ghazali, N. A. M. (2007). Ownership structure and corporate social responsibility disclosure: Some Malaysian evidence. Corporate Governance, 7(3), 251-266. https://doi.org/10.1108/14720700710756535

Herda, D. N., Taylor, M. E., \& Winterbotham, G. (2014). The effect of country-level investor protection on the voluntary assurance of sustainability reports. Journal of International Financial Management and Accounting, 25(2), 209-236. https://doi.org/10.1111/jifm.12018

Hoang, T. C., Abeysekera, I., \& Ma, S. (2018). Board diversity and corporate social disclosure: evidence from Vietnam. Journal of Business Ethics, 151(3), 833-852.

https://doi.org/10.1007/s10551-016-3260-1

Hudson, S., \& Miller, G. (2005). Ethical orientation and awareness of tourism students. Journal of Business Ethics, 62(4), 383-396. https://doi.org/10.1007/s10551-005-0850-8
Ibrahim, N. A., \& Angelidis, J. P. (1995). The corporate social responsiveness orientation of board members: Are there differences between inside and outside directors? Journal of Business Ethics, 14(5), 405-410.

https://doi.org/10.1007/BF00872102

Jensen, M. C., \& Meckling, W. H. (1979). Theory of the firm: Managerial behavior, agency costs and ownership structure. Journal of Financial Economics, 3(4), 163-231. https://doi.org/10.1016/0304-405X(76)90026-X

Kabir, R., \& Thai, H. M. (2017). Does corporate governance shape the relationship between corporate social responsibility and financial performance? Pacific Accounting Review, 29(2), 227-258. https://doi.org/10.1108/PAR-10-2016-0091

Katmon, N., Mohamad, Z. Z., Norwani, N. M., \& Farooque, O. Al. (2019). Comprehensive board diversity and quality of corporate social responsibility disclosure: evidence from an emerging market. Journal of Business Ethics, 157(2), 447-481. https://doi.org/10.1007/s10551-017-3672-6

Kelly, K. (2011). Gender equality in education: looking beyond parity - Vietnam case study (preliminary findings): women in educational leadership and management. In International Institute for Education Planning: Evidence-based Policy Forum (pp. 3-4). Paris, France.

Khan, A., Muttakin, M. B., \& Siddiqui, J. (2013). Corporate governance and corporate social responsibility disclosures: evidence from an emerging economy. Journal of Business Ethics, 114(2), 207-223. https://doi.org/10.1007/s10551-012-1336-0

Malik, F., Wang, F., Naseem, M. A., Ikram, A., \& Ali, S. (2020). Determinants of corporate social responsibility related to CEO attributes: an empirical study. SAGE Open, 10(1). https://doi.org/10.1177/2158244019899093

Milliken, F. J., \& Martins, L. L. (1996). Searching for common threads: Understanding the multiple effects of diversity in organizational groups. Academy of Management Review, 21(2), 402-433. https://doi.org/10.5465/amr.1996.9605060217

Mohamed Adnan, S., Hay, D., \& van Staden, C. J. (2018). The influence of culture and corporate governance on corporate social responsibility disclosure: A cross country analysis. Journal of Cleaner Production, 198, 820-832. https://doi.org/10.1016/j.jclepro.2018.07.057

Muttakin, M. B., Khan, A., \& Mihret, D. G. (2018). The effect of board capital and CEO power on corporate social responsibility disclosures. Journal of Business Ethics, 150(1), 41-56. https://doi.org/10.1007/s10551-016-3105-y

Naciti, V. (2019). Corporate governance and board of directors: The effect of a board composition on firm sustainability performance. Journal of Cleaner Production, 237, 117727. https://doi.org/10.1016/j.jclepro.2019.117727

Nguyen, D. T. (2018). Family involvement in ownership, control, management and firm performance: empirical evidence from Viet Nam. University of Newcastle.

Oh, W. Y., Li, Z., \& Park, S. (2016). The effects of CEO characteristics and incentives on corporate social responsibility. Corporate Responsibility: Social Action, Institutions and Governance, 162-182. https://doi.org/10.1057/9781137450722_8

Sheikh, S. (2019). An examination of the dimensions of CEO power and corporate social responsibility. Review of Accounting and Finance, 18(2), 221-244. https://doi.org/10.1108/RAF-01-2018-0034

Tran, L. D. (2017). Some legal issues on information disclosure on the stock market. Industry and Trade.

Tran, N. M., \& Pham, B. N. T. (2020). The influence of CEO characteristics on corporate environmental performance of 
SMEs: Evidence from Vietnamese SMEs. Management Science Letters, 10(8), 1671-1682.

https://doi.org/10.5267/j.msl.2020.1.013

Van, L. T. H., \& Nguyen, P. A. (2019). Corporate social responsibility and SMEs in Vietnam: A study in the textile and garment industry. Journal of Risk and Financial Management, 12(4), 174. https://doi.org/10.3390/jrfm12040174

Vu, K. A., Tower, G., \& Scully, G. (2011). Corporate communication for Vietnamese listed firms. Asian Review of Accounting, 19(2). https://doi.org/10.1108/13217341111181069

Xu, B., \& Zeng, T. (2016). Profitability, state ownership, tax reporting and corporate social responsibility: Evidence from Chinese listed firms. Social Responsibility Journal, 12(1), 2331. https://doi.org/10.1108/SRJ-06-2014-0076

Zahra, S. A., \& Pearce, J. A. (1989). Boards of directors and corporate financial performance: a review and integrative model. Journal of Management, 15(2). https://doi.org/10.1177/014920638901500208

Zhang, J. Q., Zhu, H., \& Ding, H. bin. (2013). Board composition and corporate social responsibility: an empirical investigation in the Post Sarbanes-Oxley Era. Journal of Business Ethics, 114(3), 381-392. https://doi.org/10.1007/s10551-012-1352-0 